\title{
Perinuclear Neutrophil Cytoplasmic Antibody Measurement
}

National Cancer Institute

\section{Source}

National Cancer Institute. Perinuclear Neutrophil Cytoplasmic Antibody Measurement. NCl Thesaurus. Code C147302.

The determination of the amount of perinuclear neutrophil cytoplasmic antibody present in a sample. 